\title{
Dengue Lurks During Coronavirus Disease-19 Pandemic in Indonesia: A Narrative Review
}

\author{
Wienta Diarsvitri ${ }^{1 *}$, Retno Budiarti ${ }^{2}$, Pramita Anindya Nugraheni ${ }^{3}$, M. Fathi IImawan ${ }^{4}$, Verna Biutifasari $^{5}$ \\ ${ }^{1}$ Department of Community Health, Faculty of Medicine, Universitas Hang Tuah, Surabaya, Indonesia; ${ }^{2}$ Department of \\ Microbiology, Faculty of Medicine, Universitas Hang Tuah, Surabaya, Indonesia; ${ }^{3}$ Department of Paediatrics, Faculty of \\ Medicine, Universitas Hang Tuah, Dr. Ramelan Naval Hospital, Surabaya, Indonesia; ${ }^{4}$ Department of Internal Medicine, Faculty \\ of Medicine, Universitas Hang Tuah, Surabaya, Indonesia; ${ }^{5}$ Department of Clinical Pathology, Faculty of Medicine, Universitas \\ Hang Tuah, Surabaya, Indonesia
}

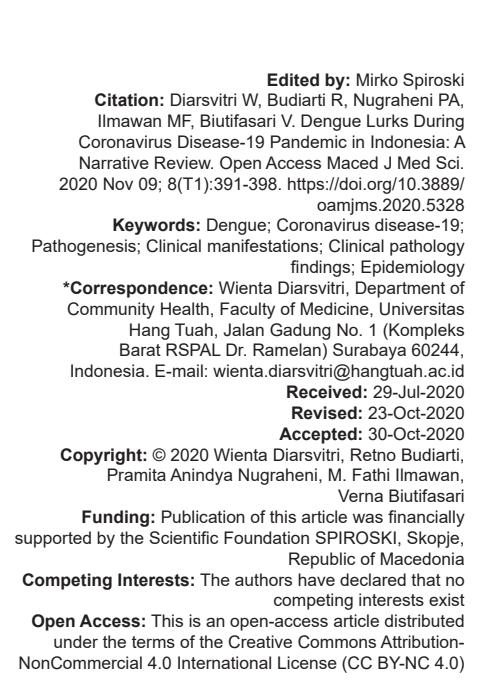

\section{Abstract}

BACKGROUND: Most attention and healthcare resources in Indonesia have been geared toward battling the coronavirus (CoV) disease (COVID)-19 pandemic, and less overture has been given to the looming risks of dengue that has been endemic in many areas of Indonesia. Despite related constraints, the Primary Health Cares (PHC) in Indonesia plays an important role in the face of emergency situations.

AIM: This study aimed to review the dengue and COVID-19 infection, clinical manifestations in children and adults, clinical pathology findings, as well as the prevention strategies that could be applied in PHC.

METHODS: This study is a narrative review based on the research articles and reports that were published between 2010 and 2020. A total of 70 articles and reports were obtained and after careful consideration, 58 articles and reports were used as references of this study.

RESULTS: Both dengue virus (DENV) and severe acute respiratory syndrome-CoV (SARS-CoV-2) share the similarity of antigenic structure, common symptoms, and laboratory findings. The immune response in SARS-CoV-2 may cause a cytokine storm, which can increase vascular permeability and organ damage. Secondary infection of DENV with different strains may allow the occurrence of antibody-dependent enhancement. The cross-reactions between SARS-CoV-2 antibodies and DENV antigens may cause false positive on rapid dengue infection serological tests.

CONCLUSION: PHC as the front line of health services has a fundamental role in the crisis situation. The prevention and control of DENV and SARS-CoV-2 infections are based on the mode of transmission and need compliance to the related health protocols.

\section{Introduction}

The Indonesia's healthcare system has been overwhelmed by the sudden struck of coronavirus (CoV) disease (COVID)-19 pandemic. After the first two confirmed cases of COVID-19 in Indonesia were reported in March 2, 2020 [1], the disease has spread rapidly to almost all parts of Indonesia that were totally unprepared for the crisis. Being the world's fourth most populous nation [2], Indonesia might suffer immensely compared to less-populous countries [3]. Based on the rising cases, fatalities, and a large-scale socioeconomic impact, on April 13, 2020, the President declared COVID-19 as a national disaster in Indonesia [4].

Most attention and healthcare resources in Indonesia have been geared toward battling the COVID19 pandemic, and less overture has been given to the looming risks of dengue, despite the fact that dengue has been endemic in many areas of Indonesia and around the period of 1968-2009, Indonesia had a history of the highest cases of dengue hemorrhagic fever (DHF) in South East Asian region [5]. As of 9 July 2020, the Ministry of Health of the Republic of Indonesia revealed that five provinces with high cases of DHF also reported a high case fatality rate (CFR) of COVID-19, namely East Java (5948 DHF cases and COVID-19 CFR 7.3\%), Special Capital Region of Jakarta (4227 DHF cases and COVID-19 CFR 5.0\%), Central Java (2846 DHF cases and COVID-19 CFR 4.3\%), West Java (10,772 DHF cases and COVID-19 CFR 3.8\%), and Bali (8930 DHF cases and COVID-19 CFR 1.3\%) [6], [7].

Both DHF and COVID-19 battle on two fronts of healthcare need. The heterogeneity of 514 districts in Indonesia by geographical features, demographical characteristics, cultures, local living styles, health-seeking behaviors, and community participations [8] creates challenges in the prevention and control strategies to combat the double burden of diseases. The introduction of universal health coverage with a single-payer system in 2014 that currently covers around 203 million people makes the Primary Health Care (PHC) Centres play 
a significant role in the face of emergency situations. Accordingly, this study aimed to review the dengue and COVID-19 infection, clinical manifestations in children and adults, clinical pathology findings, as well as the prevention strategies that could be applied in PHC.

\section{Search Strategy}

This study is a review based on the research articles and reports related to dengue virus (DENV), pathogenesis of dengue, epidemiology of dengue in Indonesia, dengue prevention, COVID-19 virology and pathogenesis, COVID-19 and DHF clinical findings, COVID-19 and DHF clinical pathology findings, epidemiology of COVID-19 in Indonesia, and COVID19 prevention that were published between 2010 and 2020. References from published articles were also included in the review, as long as they were published between 2010 and 2020. We excluded expert's point of views. A total of 70 articles and reports were obtained and after careful consideration, 58 articles and reports were used as references of this study.

\section{Indonesia}

\section{Epidemiology of DHF and COVID-19 in}

In Indonesia, DHF was first reported in Surabaya in 1968 , with a high CFR of $41.38 \%$. Dengue has spread to many areas in Indonesia and has become a public health concern since then [5]. DHF usually reaches its peak around March and diminish in the following months, which are the transition months between rainy and dry season. Nonetheless, during the COVID-19 pandemic, DHF cases in Indonesia have still been escalating with reports of more than 71,663 cases and 459 deaths from January to July 2020 , even though the recorded cases and deaths were lower compared to reports from January to July 2019 with 112,954 cases and 751 deaths [6].

The incidence rate of DHF in Indonesia (red curve in Figure 1) seemed to increase in a span of half a century, from around 0.05 cases per 100,000 person-years in 1968 to around 77.96 cases per 100,000 person-years

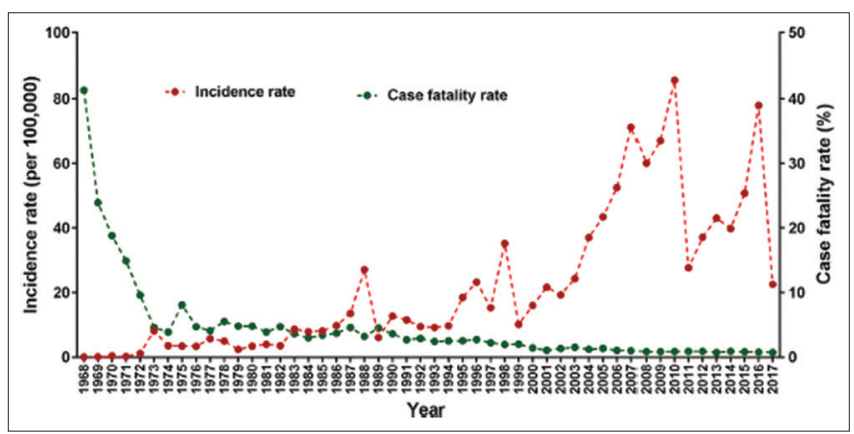

Figure 1: Incidence rate (per 100,000 person-years) and case fatality rate (\%) of dengue hemorrhagic fever in Indonesia from 1968 to 2017 [9] in 2016; with a peak of cyclic pattern occurring nearly 6-8 years. In contrast, the annual CFR of DHF has decreased afterward (green curve in Figure 1), from more than $20 \%$ in 1968 to $0.79 \%$ in 2016 [9].

In the meantime, the Ministry of Health of the Republic of Indonesia recorded the increase number of COVID-19 confirmed cases from the first two cases reported in March 2, 2020, to 365,240 confirmed cases reported on October 19, 2020 (Figure 2). There was a sharp increase in attack rate $(A R=$ percentage of confirmed cases by population size per 100,000 people) from $0.7 \%$ in March 2, 2020, to $136.4 \%$ in October 19, 2020. The calculation was based on the estimated current population of Indonesia in 2020 (267,700,000 people). There was a decrease of case positivity rate (CPR $=$ percentage of confirmed cases by number of specimens tested) from 24.1\% in April 2, 2020 to 14.3\% in October 19, 2020; an increase of case recovery rate $(\mathrm{CRR}=$ percentage of recover cases by confirmed cases) from 6.3\% in April 2, 2020 to $79.2 \%$ in October 19, 2020; and a decrease of (CFR = percentage of death cases by confirmed cases) from 9.5\% in April 2, 2020 to $3.5 \%$ in October 19, 2020 [10]. Yet, the recorded COVID-19 data might not represent the number of actual infections, which could be undetected due to several factors, including lack of proper tracing and diagnoses [3].

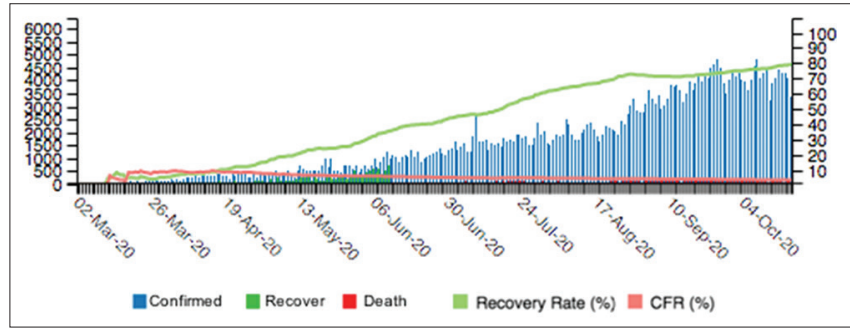

Figure 2: Number of coronavirus disease-19 confirmed cases, recover, death, RR, and CFR as of October 19, 2020 [10]

Epidemiological studies of COVID-19 may provide an insufficient representation of pediatric population. A study involving 582 children conducted in 25 European countries reported a CFR of $0.69 \%$. Conversely, CFR in infants less than a month old to adolescents with COVID-19 reach $1.1 \%$ in Indonesia [11].

\section{Dengue and severe acute respiratory syndrome-CoV (SARS-CoV-2) viruses}

DENV belongs to the Flaviviridae, a family of positive, single-stranded, enveloped RNA viruses [12]. The transmission of DENV is mediated by mosquito vectors, Aedes spp. DENV consists of four serotypes, namely, DEN-1, DEN-2, DEN-3, and DEN-4 [13].

Dengue viral genome component (Figure 3) comprises genes that encode structural proteins and non-structural proteins. The structural protein genes contain codes to form protein M (membrane), C (capsid), and $E$ (envelope), and these outer proteins 


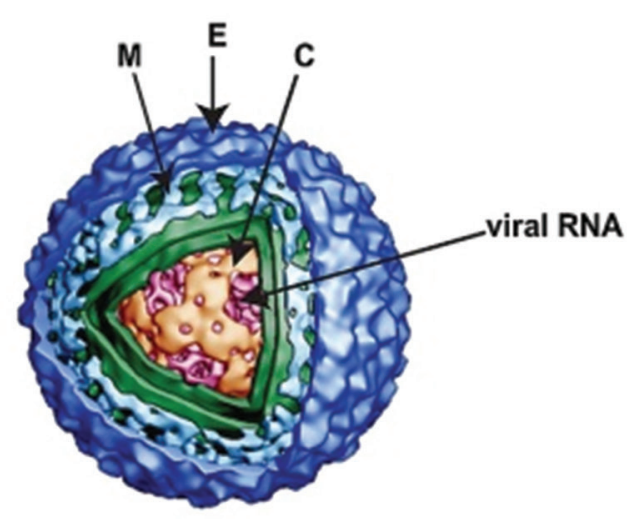

a

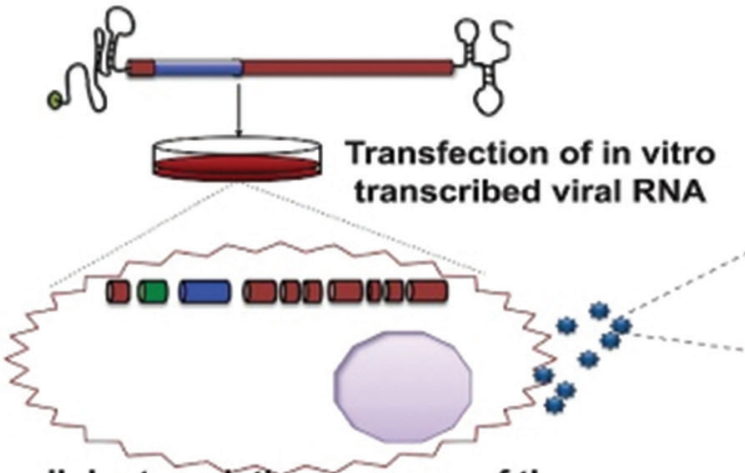

Intracellular translation, process of the polyprotein, replication of viral genomes c and assembly and release of viral particles

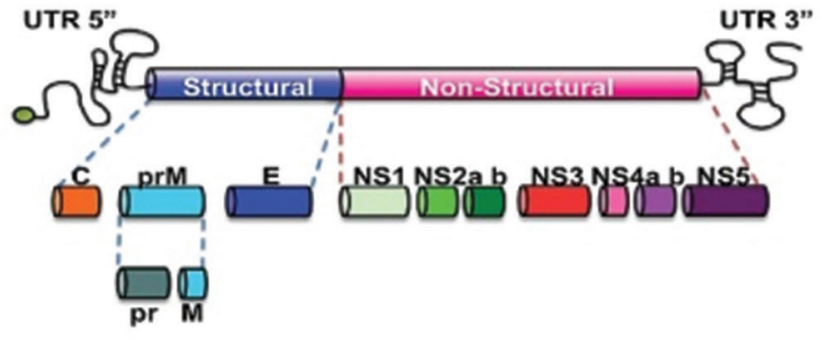

b

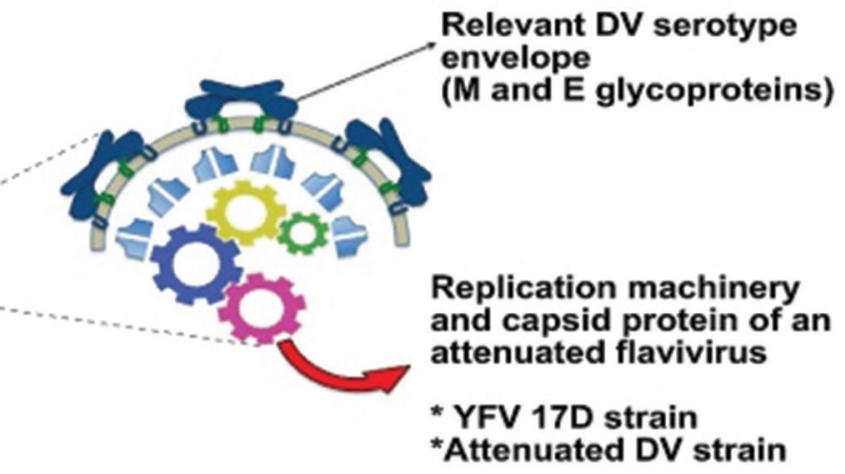

Figure 3: (a-c) Dengue viral genome component [14]

will bind to human antibodies. In contrast, the nonstructural protein genes contain codes to form enzymes that are needed for virus replication [14].

Virus that causes COVID-19 (SARS-CoV-2) is one of the Corona strains that infect humans (Figure 4). The CoV genome encodes four main proteins: spike $(\mathrm{S})$, nucleocapsid $(\mathrm{N})$, membrane $(\mathrm{M})$, and envelope (E). S protein is responsible for the entry of viruses into cells that express angiotensin-converting enzyme 2 (ACE2) receptors. Approximately $75 \%$ of the SARSCoV-2 genome is identical to the SARS-CoV genome, in which both viruses use ACE2 receptors to infect epithelial and endothelial barrier cells of the airway mucosa [17].

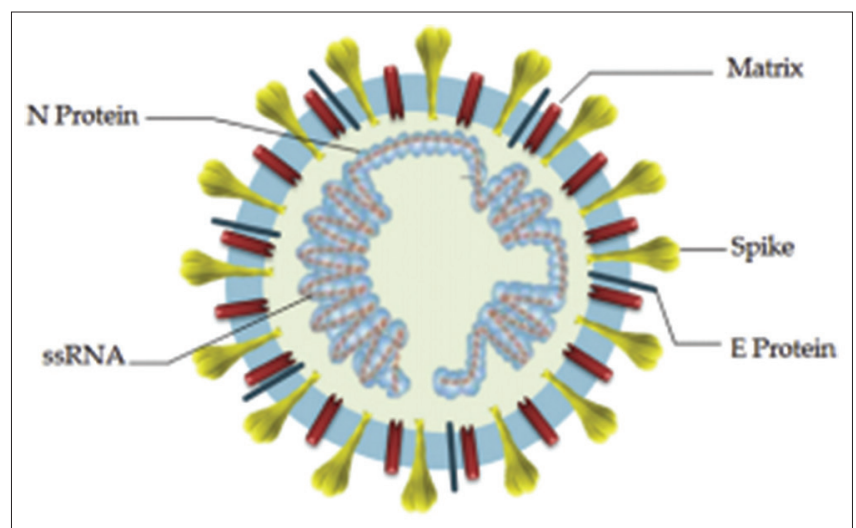

Figure 4: SARS-CoV-2 structure [15], [16]

\section{DENV Infection}

Following infection, DENV replicates in the skin cells, including keratinocytes and Langerhans cells [18], which then trigger various host innate immune responses, including macrophage [19], [20], [21]. The bonding complex between receptors on the surface of cytotoxic T cells, major histocompatibility complex I (MHC I) molecules, virus peptides, and macrophage cells will act as antigen-presenting cells. After the bonding complex occurs, CD8 cells will produce cytokines, which will cause macrophage to undergo apoptosis [22], [23], [24]. Dengue may also infect mast cells, causing degranulation and release of several inflammatory mediators, which can increase vascular permeability and vascular leakage [25], [26].

The innate and adaptive immune response phases will determine the clinical symptoms that appear in infected patients. If both systems successfully kill the DENV, then there will be a low viremia or no virus so that the patient does not show clinical symptoms (subclinical). However, if the virus remains in moderate amounts (moderate viremia), then the clinical symptoms appear as dengue fever. If the virus escapes from the immune system and lead to severe viremia, then the clinical symptoms appear as dengue hemorrhagic fever, with life-threatening emergency symptoms, such as bleeding, shock, and death [13], [14], [15], [16], [17], [18], [19], [20], [21], [22], [23], [24], [25], [26], [27]. 
DENV is also able to infect endothelial cells (Figure 5). The demise of endothelial cells by apoptosis will increase blood vessel permeability and cause plasma and red blood cell leakage, which is clinically seen as bleeding [28].

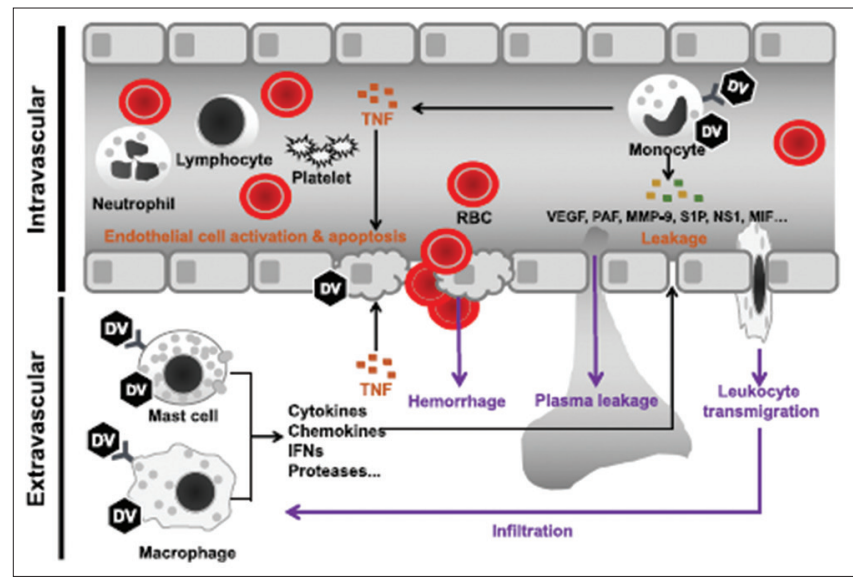

Figure 5: Pathogenesis of extra and intravascular bleeding [28]

Antibodies in dengue infection are produced by plasma cells derived from differentiation of B lymphocytes, by activation of CD4 cells through the intermediary molecule MHC II. Anti-dengue antibodies, part of host humoral pathways, are specific to DENV and will bind as lock and key to neutralize the virus [13]. The mechanism occurs in the first infection by DENV and secondary infection from the same serotype. However, if a secondary infection is caused by a different serotype of DENV (Figure 6), the antibodies assembled from the previous infection are not able to neutralize the virus from the second infection but will cause the fragment crystallizable region (Fc) antibody fragment to attach to antibody receptors on the macrophage cell surface. This attachment causes the entry of DENV into these cells and causes massive viral replication, increase in viral load, and release of several inflammatory mediators, which is referred to as antibodydependent enhancement (ADE). Clinical manifestations that occur are dengue hemorrhagic fever, dengue shock syndrome, or death [29], [30].

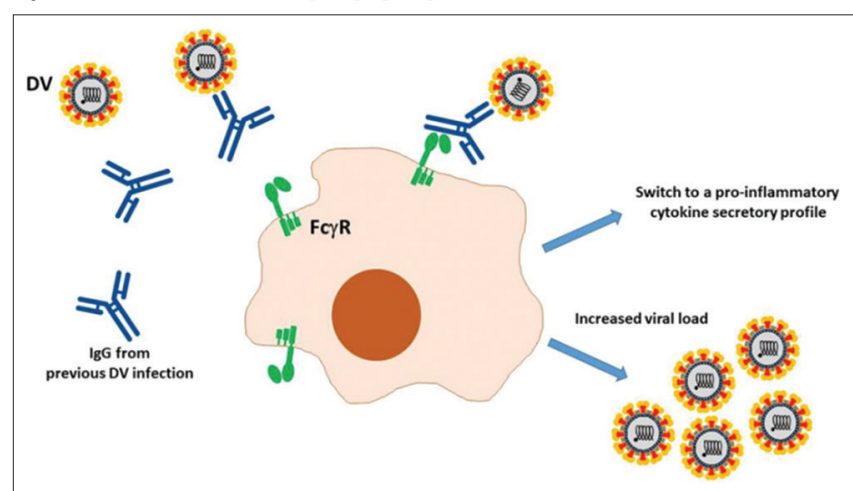

Figure 6: Pathogenesis of ADE in secondary dengue infection with different serotype [29]

\section{SARS-CoV-2 Infection}

When a CoV infects macrophage cells (Figure 7), NK cells as part of the innate immune system lyse both the infected macrophage cells and the viruses inside them. If macrophages fail to lyse the virus, they will activate CD4 cells. CD4 cells will differentiate into Th2 and Th1. Th1 cells will release inflammatory mediators to strengthen the role of macrophage cells. Whereas Th2 cells will help differentiate $B$ lymphocyte cells into plasma cells and produce specific antibodies for this virus and then act as neutralizing antibodies [31], [32].

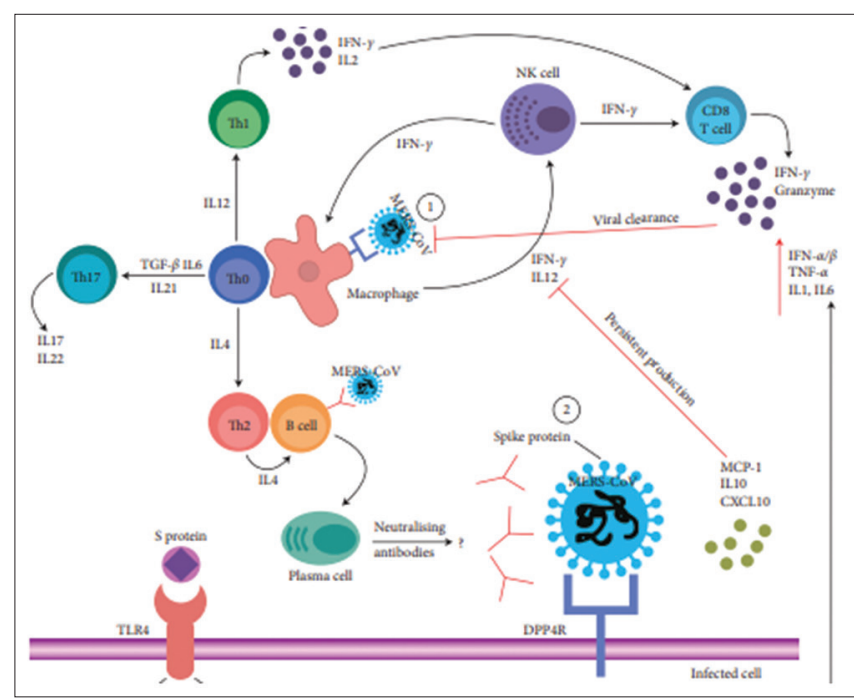

Figure 7: Immune response to coronavirus infection [32]

One of the main features of SARS-CoV-2 infection is the emergence of cytokine storms that produce an uncontrolled systemic inflammatory response from the release of pro-inflammatory cytokines and chemokines by immune cells. Cytokine storms trigger severe inflammatory responses that cause acute respiratory distress syndrome, multiple organ failure, and death [17].

\section{Dengue Fever and COVID-19 Infection}

Previous research [33] proposed a possibility of viral interference mechanism [34] of SARS-CoV-2 over DENV. SARS-CoV-2 has a high virulence and pathogenicity, and both SARS-CoV-2 and COVID-19 have a tropism toward endothelial cells [35], [36], which could lead to competitive inhibition. Dengue fever and COVID-19 may have similar clinical symptoms in the early stages and similar laboratory features [37], [38]. COVID-19 cases may be misdiagnosed as dengue, especially when relying on DENV IgM, which can remain positive months after infection [39]. Some common symptoms observed in COVID-19 and dengue patients may include fever, malaise, myalgia, headaches, and weakness [40]. COVID-19 may also produce symptoms such as cough, dyspnea and dysgeusia, sore throat, anosmia, and diarrhea, whereas adult patients with dengue may also suffer from retro-orbital pain, nausea/ vomiting, rashes, and arthralgia [39]. 
It is still puzzling why children with COVID-19 suffer less severe symptoms than adults. A previous study suggested that children might be less sensitive to SARS-CoV-2 due to the maturity and function (e.g., binding ability) of ACE2 in children may be lower than that in adults. Further, the developing immune system in children may respond differently to pathogens [41].

Some common hematological findings in COVID-19 are lymphocytopenia, neutrophilia, eosinopenia, mild thrombocytopenia, and rarely thrombocytosis [42]. Neutrophil-lymphocyte ratio (NLR) in dengue fever is inversely correlated with the degree of severity, whereas NLR in COVID-19 is in line with the severity of the disease [43]. The increase in the inflammatory factor that occurs in COVID-19 may cause a decrease in erythrogenesis and cause erythrocyte destruction, which results in anemia [44]. In addition, coagulation abnormalities often occur in COVID-19, namely an increase in prothrombin time and d-dimer [45].

In dengue-endemic areas, there is also a possibility of false-positive results in serological tests for dengue fever. Due to the similarity of antigenic structure, SARS-CoV-2 can trigger the production of anti-DENV antibodies from immunological memory of $T$ and $B$ cells derived from previous exposure to the DENV virus. The anti-DENV antibodies against dengue may cause a false positive result of rapid dengue test and fail to consider COVID-19 infection, which leads to serious implications for both patients and public health [37]. Moreover, in patients with chronic co-morbidities, overlapping infections may increase the number of the patient requiring intensive care unit and mechanical ventilation [33].

\section{Preventing DENV and SARS-CoV-2 Transmission}

A vaccine to prevent dengue is available in some countries for people ages 9-45 years old with confirmed prior DENV infection [46]. DHF prevention and control focus on breaking the life cycle of Aedes spp. mosquito vectors with biological, physical, and chemical approaches that have been part of national health programs and have been introduced to the community since 1968 [47]. The popular physical approach of DHF prevention in the community is to eradicate mosquito's breeding place by draining water reservoirs once a week, covering water reservoir, and recycling used containers [48]. The application of biological agents, which are directed against the larval stages of dengue vectors, include fish (e.g., Gambusia affinis), bacteria (e.g., Bacillus thuringiensis), Cyclopods, and autocidal ovitraps. The chemical control may include chemical larviciding, insect growth regulators, and space sprays with organophosphate insecticides [49].
In contrast, SARS-CoV-2 may be transmitted primarily through contact, respiratory droplet $(>5$ $10 \mu \mathrm{m}$ in diameter), and droplet nuclei (aerosol, $\leq 5 \mu \mathrm{m}$ in diameter) [50] when an infected person talks, coughs, sings, or sneezes [51]. However, it may also be possible to be transmitted through airborne [52], fomite (contaminated services) [53], fecal-oral [54], bloodborne, mother-to-child, and animal-to-human [55].

Many countries apply lockdown strategies to reduce the impact of COVID-19 pandemic [56]. PHC as the front line of health services has a fundamental role in the crisis situation, related to its knowledge of the catchment areas, accessibility, following up on suspected and mild cases that are directed toward restraining the pandemic and preventing the spread of the disease, as well as preventing the disease progression [56].

The prevention of COVID-19 may include washing hands with soap and water or an alcoholbased hand sanitizer; maintaining physical distance between persons; avoid going to crowded places; and avoid touching eyes, nose, and mouth [57], [58]. The health protocols to prevent the transmission of SARSCoV-2 have been applied in workplaces, schools, health-care facilities, homes, and other public places in Indonesia [58], and compliance to the health protocols is needed.

\section{Conclusion}

Both DENV and SARS-CoV-2 share similarity of antigenic structure, common symptoms, and laboratory findings. The immune response in SARS-CoV-2 may cause cytokine storm, which can increase vascular permeability and organ damage. Secondary infection of DENV with different strains may allow the occurrence of ADE. The cross-reactions between SARS-CoV-2 antibodies and DENV antigens may cause false positive on rapid dengue infection serological tests. DENV is transmitted by Aedes spp., whereas SARSCoV-2 may be transmitted through contact, respiratory droplet, aerosol, and other modes.

The sudden struck of COVID-19 pandemic and the surge of dengue causes a huge impact on health-care system in Indonesia. PHC as the front line of health services has a fundamental role in the crisis situation in restraining the pandemic and preventing the spread of the disease, as well as preventing the disease progression. The prevention and control of DENV and SARS-CoV-2 infections are based on the mode of transmission and need compliance to the related health protocols. 


\section{Authors' Contributions}

Study design: WD and RB. Data acquisition: WD, RB, PAN, MFI, and VB. Drafting of manuscript: WD and RB. Critical revision of the manuscript: WD, $\mathrm{RB}, \mathrm{PAN}, \mathrm{MFI}$, and VB.

\section{References}

1. Ministry of Health of the Republic of Indonesia. Recent Situation of Novel Coronavirus (COVID-19). Jakarta: Ministry of Health of the Republic of Indonesia; 2020.

2. The World Bank. The World Bank in Indonesia. Washington, D.C: The World Bank; 2020. p. 1.

3. Djalante R, Lassa J, Setiamarga D, Sudjatma A, Indrawan M, Haryanto $\mathrm{B}$, et al. Review and analysis of current responses to COVID-19 in Indonesia: Period of January to March 2020. Prog Disaster Sci. 2020;6:100091. https://doi.org/10.1016/j. pdisas.2020.100091

4. World Health Organization Indonesia. Coronavirus Disease 2019 (COVID-19) Situation Report-4. Geneva: World Health Organization Indonesia; 2020.

5. Soepardi J, Brahim R, Hasnawati, Anggraeni ND, Ismandari F. Dengue Hemorrhagic Fever in Indonesia 1968-2009. Bul Jendela Epidemiol. 2010;2:1-13.

6. Ministry of Health of the Republic of Indonesia. Until July, Dengue Cases in Indonesia Reached 71 Thousand. Jakarta: Ministry of Health of the Republic of Indonesia; 2020. p. 1.

7. Ministry of Health of the Republic of Indonesia. Recent Situation of Novel Coronavirus (COVID-19). Data Reported Until 9 July 2020. Jakarta: Ministry of Health of the Republic of Indonesia; 2020. Available from: https://www.infeksiemerging.kemkes. go.id/download/Situasi_Terkini_100720.pdf. [Last accessed on 20 Oct 2020].

8. Agustina R, Dartanto T, Sitompul R, Susiloretni KA, Suparmi MK, Achadi EL, et al. Universal health coverage in Indonesia: Concept, progress, and challenges. Lancet. 2019;393(10166):75-102. https://doi.org/10.1016/s0140-6736(18)31647-7 PMid:30579611

9. Harapan H, Michie A, Mudatsir M, Sasmono RT, Imrie A. Epidemiology of dengue hemorrhagic fever in Indonesia: Analysis of five decades data from the national disease surveillance. BMC Res Notes. 2019;12(1):350. https://doi. org/10.1186/s13104-019-4379-9

PMid:31221186

10. Ministry of Health of the Republic of Indonesia. COVID-19 Update until 19 October 2020. Jakarta: Ministry of Health of the Republic of Indonesia; 2020. Available from: https://www. infeksiemerging.kemkes.go.id.

11. Pulungan AB. The covid-19 pandemic and Asia-Pacific children. Asia Pac J Pediatr Child Health. 2020;3:57-8.

12. Centers for Disease Control and Prevention. Viral Hemorrhagic Fevers (VHFs). Flavivirus. Atlanta: Centers for Disease Control and Prevention; 2013. p. 1.

13. Martina BE, Koraka P, Osterhaus AD. Dengue virus pathogenesis: An integrated view. Clin Microbiol Rev. 2009;22(4):564-81. https://doi.org/10.1128/cmr.00035-09 PMid:19822889

14. deAngelRM, Reyes-delValle J. Denguevaccines: Strongly sought but not a reality just yet. PLoS Pathog. 2013;9(10):e1003551. https://doi.org/10.1371/journal.ppat.1003551

PMid:24098108

15. Schoeman D, Fielding BC. Coronavirus envelope protein: Current knowledge. Virol J 2019;16(1):69. https://doi. org/10.1186/s12985-019-1182-0

PMid:31133031

16. Tai $\mathrm{W}$, He L, Zhang $\mathrm{X}, \mathrm{Pu} \mathrm{J}$, Voronin $\mathrm{D}$, Jiang $\mathrm{S}$, et al. Characterization of the receptor-binding domain (RBD) of 2019 novel coronavirus: Implication for development of RBD protein as a viral attachment inhibitor and vaccine. Cell Mol Immunol. 2020;17(6):613-20. https://doi.org/10.1038/s41423-020-0400-4 PMid:32203189

17. Nile SH, NileA, Qiu J, Li L, Jia X, Kai G. COVID-19: Pathogenesis, cytokine storm and therapeutic potential of interferons. Cytokine Growth Factor Rev. 2020;53:66-70. https://doi.org/10.1016/j. cytogfr.2020.05.002

PMid:32418715

18. Garcia $M$, Wehbe $M$, Lévêque $N$, Bodet $C$. Skin innate immune response to flaviviral infection. Eur Cytokine Netw. 2017;28(2):41-51. https://doi.org/10.1684/ecn.2017.0394 PMid:28840835

19. Samuel CE. Antiviral actions of interferons. Clin Microbio Rev. 2001;14(4):778-809. https://doi.org/10.1128/ cmr.14.4.778-809.2001 PMid: 11585785

20. Cha L, Berry CM, Nolan D, Castley A, Fernandez S, French MA Interferon-alpha, immune activation and immune dysfunction in treated HIV infection. Clin TransI Immunol. 2014;3(2):e10. https://doi.org/10.1038/cti.2014.1 PMid:25505958

21. Shereen MA, Khan S, Kazmi A, Bashir N, Siddique R. COVID19 infection: Origin, transmission, and characteristics of human coronaviruses. J Adv Res. 2020;24:91-8. https://doi. org/10.1016/j.jare.2020.03.005 PMid:32257431

22. Laing K, Hutchinson F. "Immune Responses to Viruses". London, United Kingdom: British Society for Immunology; 2014 Available from: https://www.immunology.org/public-information/ bitesized-immunology/pathogens-and-disease/immuneresponses-viruses. [Last accessed on 20 Oct 2020].

23. Mak T, Saunders M, Jett B. "Immunity to Infection." In: Primer to the Immune Response. $2^{\text {nd }}$ ed. Cambridge, Massachusetts: Academic Cell; 2014. p. 295-332.

24. Pulendran B, Oh JZ, Nakaya HI, Ravindran R, Kazmin DA. Immunity to viruses: Learning from successful human vaccines. Immunol Rev. 2013;255(1):243-55. https://doi.org/10.1111/ imr.12099

PMid:23947360

25. Hasan S, Jamdar SF, Alalowi M, Al Ageel Al Beaiji SM Dengue virus: A global human threat: Review of literature. J Int Soc Prev Community Dent. 2016;6(1):1-6. https://doi. org/10.4103/2231-0762.175416 PMid:27011925

26. St John AL. Influence of mast cells on dengue protective immunity and immune pathology. PLoS Pathog. 2013;9(12):e1003783. https://doi.org/10.1371/journal.ppat.1003783

PMid:24367254

27. Rothman AL, Medin CL, Friberg $\mathrm{H}$, Currier JR. Immunopathogenesis versus protection in dengue virus infections. Curr Trop Med Rep. 2014;1(1):13-20. https://doi. org/10.1007/s40475-013-0009-0 PMid:24883262

28. Wan SW, Wu-Hsieh BA, Lin $Y S$, Chen WY, Huang $Y$ Anderson R. The monocyte-macrophage-mast cell axis in 
dengue pathogenesis. J Biomed Sci. 2018;25(1):77. https://doi. org/10.1186/s12929-018-0482-9

PMid:30409217

29. Negro F. Is antibody-dependent enhancement playing a role in COVID-19 pathogenesis? Swiss Med Wkly. 2020;150:w20249. https://doi.org/10.4414/smw.2020.20249

PMid:32298458

30. Ulrich H, Pillat MM, Tárnok A. Dengue fever, covid-19 (SARSCoV-2), and antibody-dependent enhancement (ADE): A perspective. Cytometry A. 2020;19(2):662-7. https://doi. org/10.1002/cyto.a.24047

PMid:32506725

31. Merad M, Martin JC. Pathological inflammation in patients with COVID-19: A key role for monocytes and macrophages. Nat Rev Immunol. 2020;20(6):355-62. https://doi.org/10.1038/ s41577-020-0331-4

PMid:32376901

32. Mubarak A, Alturaiki W, Hemida MG. Middle east respiratory syndrome coronavirus (mers-cov): Infection, immunological response, and vaccine development. J Immunol Res. 2019;2019:6491738. https://doi.org/10.1155/2019/6491738

33. Cardona-Ospina JA, Arteaga-Livias K, Villamil-Gómez WE, Pérez-Díaz CE, Bonilla-Aldana DK, Mondragon-Cardona A, et al. "Dengue and COVID-19, overlapping epidemics? An analysis from Colombia. J Med Virol. 2020. Available from: https://onlinelibrary.wiley.com/doi/epdf/10.1002/jmv.26194. [Last accessed on 20 Oct 2020].

PMid:32558962

34. Pinky L, Dobrovolny HM. Coinfections of the respiratory tract: Viral competition for resources. PLoS One. 2016;11(5):e0155589. https://doi.org/10.1371/journal.pone.0155589

PMid:27196110

35. Guzik TJ, Mohiddin SA, Dimarco A, Patel V, Savvatis K, MarelliBerg FM, et al. COVID-19 and the cardiovascular system: Implications for risk assessment, diagnosis, and treatment options. Cardiovasc Res. 2020;116(10):1666-87. https://doi. org/10.1093/cvr/cvaa106

PMid:32352535

36. Wilder-Smith A, Ooi EE, Horstick O, Wills B. Dengue. Lancet. 2019;393(10169):350-63. https://doi.org/10.1016/ s0140-6736(18)32560-1

PMid:30696575

37. Yan G, Lee CK, Lam LT, Yan B, Chua YX, Lim AY, et al. Covert COVID-19 and false-positive dengue serology in Singapore. Lancet Infect Dis. 2020;20(5):536. https://doi.org/10.1016/ s1473-3099(20)30158-4

PMid:32145189

38. Chen N, Zhou M, Dong X, Qu J, Gong F, Han Y, et al. Epidemiological and clinical characteristics of 99 cases of 2019 novel coronavirus pneumonia in Wuhan, China: A descriptive study. Lancet. 2020;395(10223):507-13. https://doi.org/10.1016/ s0140-6736(20)30211-7

PMid:32007143

39. Lokida D, Lukman N, Salim G, Butar DP, Kosasih H, Wulan WN, et al. Diagnosis of COVID-19 in a dengue-endemic area. Am J Trop Med Hyg. 2020;103(3):1220-2. https://doi.org/10.4269/ ajtmh.20-0676

PMid:32762798

40. Lorenz C, Azevedo TS, Chiaravalloti-Neto F. COVID-19 and dengue fever: A dangerous combination for the health system in Brazil. Travel Med Infect Dis. 2020;35:101659. https://doi. org/10.1016/j.tmaid.2020.101659

PMid:32278756

41. Dong $\mathrm{Y}$, Dong $\mathrm{Y}, \mathrm{Mo} \mathrm{X}, \mathrm{Hu} \mathrm{Y}, \mathrm{Qi} \mathrm{X}$, Jiang $\mathrm{F}$, et al.
Epidemiology of COVID-19 among children in China. Pediatrics. 2020;145(6):e20200702. https://doi.org/10.1542/ peds.2020-0702

PMid:32179660

42. de Oliveira Toledo SL, Nogueira LS, das Graças Carvalho M, Rios DR, de Barros Pinheiro M. COVID-19: Review and hematologic impact. Clin Chim Acta. 2020;510:170-6. https:// doi.org/10.1016/j.cca.2020.07.016

PMid:32659224

43. Pimentel GD, Vega MC, Laviano A. High neutrophil to lymphocyte ratio as a prognostic marker in COVID-19 patients. Clin Nutr ESPEN. 2020. Available from: https://www.ncbi.nlm. nih.gov/pmc/articles/PMC7427597/pdf/main.pdf. [Last access on 20 Oct 2020].

44. Sun S, Cai X, Wang H, He G, Lin Y, Lu B, et al. Abnormalities of peripheral blood system in patients with COVID-19 in Wenzhou, China. Clin Chim Acta. 2020;507:174-80. https://doi. org/10.1016/j.cca.2020.04.024

PMid:32339487

45. Huang C, Wang Y, Li X, Ren L, Zhao J, Hu Y, et al. Clinical features of patients infected with 2019 novel coronavirus in Wuhan, China. Lancet. 2020;395(10223):497-506. https://doi. org/10.1016/s0140-6736(20)30183-5 PMid:31986264

46. Centers for Disease Control and Prevention. Dengue vaccine globally. Atlanta: Centers for Disease Control and Prevention; 2019. p. 1.

47. Kusriastuti R, Sutomo S. Evolution of dengue prevention and control programme in Indonesia. Dengue Bull. 2005;29:1-7.

48. Ministry of Health of the Republic of Indonesia. Beware of DHF, Prevent with $3 \mathrm{M}$ Plus. Jakarta: Ministry of Health of the Republic of Indonesia; 2020. p. 1.

49. World Health Organization. World Health Organization, and Regional Office for South-East Asia. Comprehensive Guidelines for Prevention and Control of Dengue and Dengue Haemorrhagic Fever. Revised and Expanded ed. SEARO Technical. Geneva: World Health Organization; 2011. p. 212.

50. World Health Organization. Infection Prevention and Control of Epidemic and Pandemic-prone Acute Respiratory Infections in Health Care. WHO Guidelines. Geneva: World Health Organization; 2014. p. 156.

51. Liu J, Liao X, Qian S, Yuan J, Wang F, Liu Y, et al. Community transmission of severe acute respiratory syndrome coronavirus 2, Shenzhen, China, 2020. Emerg Infect Dis. 2020;26(6):13203. https://doi.org/10.3201/eid2606.200239 PMid:32125269

52. World Health Organizaton. Advice on the Use of Masks in the Context of COVID-19. Geneva: World Health Organizaton; 2020. p. 16.

53. Van Doremalen N, Bushmaker T, Morris DH, Holbrook MG, Gamble A, Williamson BN, et al. Aerosol and surface stability of SARS-CoV-2 as compared with SARS-CoV-1. N Engl J Med. 2020;382(16):1564-7. https://doi.org/10.1056/nejmc2004973 PMid:32182409

54. Wang W, Xu Y, Gao R, Lu R, Han K, Wu G, et al. Detection of SARS-CoV-2 in different types of clinical specimens. JAMA. 2020;323(18):1843-4. https://doi.org/10.1001/jama.2020.3786 PMid:32159775

55. World Health Organization. Transmission of SARS-CoV-2 Implications for infection prevention precautions. Geneva: World Health Organization; 2020.

56. Sarti TD, Lazarini WS, Fontenelle LF, Almeida AP. What is the role of primary health care in the COVID-19 pandemic? Epidemiol Serv Saude. 2020;29(2):e2020166.

PMid:32348404 
57. World Health Organization. Coronavirus Disease (COVID-19) Advice for the Public. Geneva: World Health Organization; 2020. p. 6.

58. Ministry of Health of the Republic of Indonesia. Minister of Health of the Republic of Indonesia Decree No. HK.01.07/
Menkes/382/2020 about Health Protocol for Communities in Public Places and Facilities to Prevent and Control Corona Virus Disease 2019 (COVID-19). Indonesia: Ministry of Health of the Republic of Indonesia; 2020. p. 66. 